\title{
The Effect of Rewards and Punishment on Employee Performance at Daima Hotel Padang
}

\author{
Lise Asnur ${ }^{1}$, Desri Yeni ${ }^{2}$ \\ \{lise.asnur@fpp.unp.ac.id \} \\ Tourism Department, Universitas Negeri Padang, Indonesia ${ }^{12}$
}

\begin{abstract}
Research intends to determine There is an effect of reward and punishment on the performance of Daima Hotel Padang employees. This research uses associative causal quantitative data using a survey method, with a total sample of 49 people, using a saturated sampling technique. Data were collected from the results of filling out a questionnaire using the scale method Likert. Furthermore, data analysis using multiple linear regression tests. Based on the hypothesis testing, the results reward with a coefficient value of 0.318 and significant $0.00<0.05$, then the reward has an influence on employee performance, the employee performance. punishment is obtained by a coefficient value of 0.519 and significant $0.00<0.05$, then punishment has an effect on employee performance. The decision-making hypothesis, namely the F test, obtained an $\mathrm{F}$ count of 11.797 with a significance of $0.000<0.05$, meaning that reward and punishment simultaneously have an influence on employee performance, the contribution of influence is obtained, namely $39.9 \%$, then $60.1 \%$ is influenced by other factors.
\end{abstract}

Keywords: Reward; Punishment and Employee Performance

\section{Introduction}

One of the world's tourist destinations in Indonesia because it is unique and the beauty of tourism. Law No. 10 of 2009 states that the purpose of tourism is to increase economic growth, improve welfare, eliminate poverty, conserve nature, the environment and resources, and promote culture. To achieve this, tourism activities should be supported by the availability of accommodation such as hotels, guesthouses and other types of accommodation. Based on PPRI No.65, it explains that a hotel is a building provided for people to stay and get services and facilities for a fee. One of the star hotels in the city of Padang is Daima Hotel Padang which is located on Jalan Jendral Sudirman No.17, Padang City, which is classified as a threestar hotel. HR is an important asset of a company. Mangkunegara (2015: 2), Human Resources is a planning, organizing, coordinating, implementing, and supervising the procurement, development, remuneration, integration, maintenance and separation of labor in order to achieve organizational goals, employees can become potentials if managed properly because management will affect employee performance. According to Dharma in Widyaningsih (2017), there are several factors that affect performance, namely expectations that are burdened by consequences (reward and punishment).

Furthermore, Wibowo (2016: 306), for the work and results obtained, workers get a salary further in improving manager performance providing incentives for workers who can provide work performance that exceeds the expected performance standards, besides that the leader 
also provides additional appreciation for the worker's performance, namely giving awards (reward). Then Mangkunegara (2013: 130), punishment is the threat of punishment to improve the performance of employees who violate and maintain applicable regulations and provide lessons for violators. Rewards given at Daima Hotel Padang are in the form of a certificate best employee which is held once in three months and there is no increase in salary. So that there are employees who are not happy and neglect work such as employees who often arrive late, lack discipline towards work, leave work before their time and take off for 3 consecutive days. So, the management gives punishment with the aim that employees who make mistakes do not repeat it again.

\section{Methodology}

research is a causal associative type of quantitative data and survey methods. The population is all operational employees of Daima Hotel Padang totaling 49 people with saturated sampling type where all employees are sampled. The instrument in the study used the scale answer choices Likert. The classification technique in this study was proposed by Arikunto (2010: 239) which was determined based on the ideal average score with normal curve benchmarks, namely MI and SDI. The technique of data analysis requirements was carried out with 3 types of tests, namely normality, homogeneity, and linearity. Variable data analysis was carried out using multiple linear regression, and hypothesis making using the $\mathrm{F}$ test which determines whether or not the dependent variable influences the independent variable simultaneously.

\section{Result and Discussion}

\subsection{Data Description Variable Reward (X1)}

Based on the distribution of a questionnaire from 15 statement items, the results of the variable reward are as follows:

Table 1. Descriptive Data Variable Reward Daima Hotel Padang

\begin{tabular}{|c|c|c|c|}
\hline Category & Score Range & Frequency & $\%$ \\
\hline Very Good & $\geq 60$ & 0 & 0 \\
\hline Good & $50-<60$ & 8 & 16.32 \\
\hline Sufficient & $40-<50$ & 39 & 79.59 \\
\hline Poor & $30-<40$ & 2 & 4.08 \\
\hline Very Bad & $<30$ & 0 & 0 \\
\hline \multicolumn{2}{|c|}{ Total } & 49 & 100 \\
\hline
\end{tabular}

The descriptive data table explains that: $16.32 \%$ good category, $79.59 \%$ sufficient, and $4.08 \%$ bad. So, it can be concluded that the reward for Daima Hotel Padang is considered 
quite good. Furthermore, a descriptive table of data from indicators is presented reward, namely:

a. Salary and Bonus

Table 2. Descriptive Data of Salaries and Bonuses for Daima Hotels in Padang

\begin{tabular}{|c|c|c|c|}
\hline Category & Range of Score & Frequency & $\%$ \\
\hline Very Good & $\geq 15.9$ & 6 & 12.24 \\
\hline Good & $13.3-<15.9$ & 15 & 30.61 \\
\hline Sufficient & $10.7-<13.3$ & 16 & 32.65 \\
\hline Poor & $8.1-<10.7$ & 9 & 18.36 \\
\hline Very Bad & $<8.1$ & 3 & 6.12 \\
\hline \multicolumn{2}{|c|}{ Total } & 49 & 100 \\
\hline
\end{tabular}

Descriptive table of respondent data explained that: $12,24 \%$ of the categories are very good, $30.61 \%$ are good, $32.65 \%$ are sufficient, $18.36 \%$ are bad, and $6.12 \%$ are very bad. So, it can be concluded that the salary and bonuses of Daima Hotel Padang are considered quite good.

b. Welfare

Table 3. Descriptive Welfare Data of Daima Hotel Padang

\begin{tabular}{|c|c|c|c|}
\hline Category & Score Range & Frequency & $\%$ \\
\hline Very Good & $\geq 15.9$ & 2 & 4.08 \\
\hline Good & $13.3-<15.9$ & 11 & 22.44 \\
\hline Enough & $10.7-<13.3$ & 23 & 46,93 \\
\hline Poor & $8.1-<10.7$ & 12 & 24.48 \\
\hline Very Bad & $<8.1$ & 1 & 2.04 \\
\hline \multicolumn{2}{|c|}{ Total } & 49 & 100 \\
\hline
\end{tabular}

The descriptive data table explains that: $4.08 \%$ very good category, $22.44 \%$ good, 46.93 $\%$ fair, $24.48 \%$ bad, and $2.04 \%$ very good. So it can be concluded that the welfare of Daima Hotel Padang is considered quite good.

c. Career Development

Table 4. Descriptive Career Development Data of Daima Hotel Padang

\begin{tabular}{cccc}
\hline Category & Score Range & Frequency & $\%$ \\
\hline Very Good & $\underline{12}$ & 8 & 16.32
\end{tabular}




\begin{tabular}{ccccc} 
Good & $\mathbf{1 0}-<\mathbf{1 2}$ & $\mathbf{2 4}$ & $\mathbf{4 8 . 9 7}$ \\
Enough & $8-<10$ & 10 & 20.40 \\
Poor & $6-<10$ & 5 & 10,20 \\
Very Bad & $<6$ & 2 & 4.08 \\
& Total & & $\mathbf{4 9}$ & $\mathbf{1 0 0}$ \\
\hline
\end{tabular}

The descriptive data table explains that: $16.32 \%$ very good category, $48.97 \%$ good, $20.48 \%$ sufficient, $10.20 \%$ bad, and $4.08 \%$ very bad. So, it can be concluded that the career development of Daima Hotel Padang is considered good.

d. Psychological and Social Awards

Table 5. Descriptive Data of Psychological and Social Awards of Daima Hotel Padang

\begin{tabular}{|c|c|c|c|}
\hline Category & Score Range & Frequency & $\%$ \\
\hline Very Good & $\geq 15.9$ & 4 & 8.16 \\
\hline Good & $13.3-<15.9$ & 7 & 14.28 \\
\hline Enough & $10.7-<13.3$ & 21 & 42.85 \\
\hline Poor & $8.1-<10.7$ & 11 & 22.44 \\
\hline Very Bad & $<8.1$ & 6 & 12.24 \\
\hline \multicolumn{2}{|c|}{ Total } & 49 & 100 \\
\hline
\end{tabular}

The descriptive data table explains that: $8.16 \%$ very good category, $14.28 \%$ good, $42.85 \%$ fair, $22.44 \%$ bad, and $12.24 \%$ very bad. So, it can be concluded that the psychological and social awards of Daima Hotel Padang are considered quite good.

\subsection{Data Description Variable Punishment The}

Research data were obtained from the answers to the statements as many as 8 items filled in by all respondents.

Table 6. Data Descriptive Variable Punishment Daima Hotel Padang

\begin{tabular}{|c|c|c|c|}
\hline Category & Score Range & Frequency & $\%$ \\
\hline Very Good & $\geq 31.9$ & 0 & 0 \\
\hline Good & $26.6-<31.9$ & 6 & 12.24 \\
\hline Fair & $21.3-<26.6$ & 21 & 42.85 \\
\hline Poor & $16.1-<21.3$ & 22 & 44.89 \\
\hline Very Bad & $<16.1$ & 0 & 0 \\
\hline \multicolumn{2}{|c|}{ Total } & 49 & 100 \\
\hline
\end{tabular}


The descriptive data table explains that: $10.20 \%$ very good category, $12.24 \%$ was good, $28.57 \%$ was fair, $42.85 \%$ was bad, and $6.12 \%$ was very bad. So, it was concluded that the light punishment given to employees of the Daima Hotel Padang was considered bad. Furthermore, a descriptive table of data from the indicator is presented punishment, namely:

a. Light Punishment

Table 7. Descriptive Data for Minor Punishment at Daima Hotel Padang

\begin{tabular}{|c|c|c|c|}
\hline Category & Range of Score & Frequency & $\%$ \\
\hline Very Good & $\geq 7.9$ & 5 & 10.20 \\
\hline Good & $6,6-<7,9$ & 6 & 12,24 \\
\hline Enough & $5,3-<6,6$ & 14 & 28,57 \\
\hline Poor & $4-<5,3$ & 21 & 42,85 \\
\hline Very Bad & $<4$ & 3 & 6,12 \\
\hline \multicolumn{2}{|c|}{ Total } & 49 & 100 \\
\hline
\end{tabular}

The descriptive data table explains that: $10.20 \%$ very good category, $12.24 \%$ was good, $28.57 \%$ was fair, $42.85 \%$ was bad, and $6.12 \%$ was very bad. So, it was concluded that the light punishment given to employees of the Daima Hotel Padang was considered bad.

b. Moderate Punishment

Table 8. Descriptive Data of Moderate Punishment Daima Hotel Padang

\begin{tabular}{|c|c|c|c|}
\hline Category & Score Range & Frequency & $\%$ \\
\hline Very Good & 12 & 0 & 0 \\
\hline Good & $10-<12$ & 0 & 0 \\
\hline Fair & $8-<10$ & 0 & 0 \\
\hline Bad & $6-<10$ & 25 & 51.02 \\
\hline Very Bad & $<6$ & 24 & 48.97 \\
\hline \multicolumn{2}{|c|}{ Total } & 49 & 100 \\
\hline
\end{tabular}

The descriptive data table explains that: $51.02 \%$ is in the bad category, and $48.97 \%$ is very bad. So, it was concluded that the punishment was moderate given to employees of Daima Hotel Padang is considered bad.

c. Heavy Punishment

Table 9. Descriptive Data of Daima Hotel Padang Heavy Penalties

\begin{tabular}{cccc} 
Category & Range Score & Frequency & $\%$ \\
\hline Very Good & $\underline{12}$ & 2 & 4.08 \\
Good & $10-<12$ & 10 & 20.40
\end{tabular}




\begin{tabular}{ccccc} 
Enough & & $\mathbf{8}-<\mathbf{1 0}$ & $\mathbf{2 7}$ & $\mathbf{5 5 , 1 0}$ \\
Bad & $6-<10$ & 10 & 20.40 \\
Very Bad & & $<6$ & 0 & 0 \\
& Total & & $\mathbf{4 9}$ & $\mathbf{1 0 0}$ \\
\hline
\end{tabular}

\subsection{Data Description of Employee Performance Variables}

Research data obtained from the answers to statements as many as 12 items filled in by all respondents.

Table 10. Descriptive Data Variable Employee Performance

\begin{tabular}{|c|c|c|c|}
\hline Category & Score Range & Frequency & $\%$ \\
\hline Very Good & $\geq 48$ & 2 & 4.08 \\
\hline Good & $40-<48$ & 42 & 85.71 \\
\hline Enough & $32-<40$ & 5 & 10.20 \\
\hline Poor & $24-<32$ & 0 & 0 \\
\hline Very Bad & $<24$ & 0 & 0 \\
\hline \multicolumn{2}{|c|}{ Total } & 49 & 100 \\
\hline
\end{tabular}

The descriptive data table explains that: $4.08 \%$ very good category, $85,71 \%$ good, and $10.20 \%$ sufficient. So it can be concluded that the employee performance of Daima Hotel Padang is considered good. Furthermore, a descriptive table of data from employee performance indicators is presented, namely:

a. Knowledge About Work

Table 11. Descriptive Data Knowledge About the Work of Daima Hotel Padang

\begin{tabular}{|c|c|c|c|}
\hline Category & Range of Score & Frequency & $\%$ \\
\hline Very Good & $\geq 7.9$ & 14 & 28.57 \\
\hline Good & $6.6-<7.9$ & 16 & 32.65 \\
\hline Fair & $5,3-<6,6$ & 13 & 26,53 \\
\hline Poor & $4-<5,3$ & 6 & 12,24 \\
\hline Very Bad & $<4$ & 0 & 0 \\
\hline \multicolumn{2}{|c|}{ Total } & 49 & 100 \\
\hline
\end{tabular}

The descriptive data table explains that: $28.57 \%$ very good category, $32.65 \%$ is good, $26.53 \%$ is sufficient, and $12.24 \%$ is bad. So, it is concluded that knowledge of work Daima Hotel Padang employees are considered good. 
b. Work Quality

Table 12. Descriptive Data Quality of Work at Daima Hotel Padang

\begin{tabular}{|c|c|c|c|}
\hline Category & Range Score & Frequency & $\%$ \\
\hline Very Good & $\geq 7.9$ & 26 & 53.06 \\
\hline Good & $6.6-<7.9$ & 14 & 28.57 \\
\hline Enough & $5.3-<6.6$ & 8 & 16.32 \\
\hline Poor & $4-<5.3$ & 1 & 2.04 \\
\hline Very Bad & $<4$ & 0 & 0 \\
\hline \multicolumn{2}{|c|}{ Total } & 49 & 100 \\
\hline
\end{tabular}

The descriptive data table explains that: $53.06 \%$ very good category, $28.57 \%$ good, $16.32 \%$ sufficient, and $2.04 \%$ bad. So, it is concluded that the quality of work Daima Hotel Padang employees are considered very good.

c. Work Quantity

Table 13. Descriptive Data of Daima Hotel Padang Hotel Work Quantity

\begin{tabular}{|c|c|c|c|}
\hline Category & Score Range & Frequency & $\%$ \\
\hline Very Good & $\geq 7.9$ & 20 & 40.81 \\
\hline Good & $6.6-<7.9$ & 14 & 28.57 \\
\hline Enough & $5.3-<6.6$ & 9 & 18.36 \\
\hline Poor & $4-<5.3$ & 6 & 12.24 \\
\hline Very Bad & $<4$ & 0 & 0 \\
\hline \multicolumn{2}{|c|}{ Total } & 49 & 100 \\
\hline
\end{tabular}

The descriptive data table explains that: $40.81 \%$ is a very good category, $28.57 \%$ is good, $18.36 \%$ is sufficient, and $12.24 \%$ is bad. So it is concluded that the quantity of labor Daima Hotel Padang employees are considered very good.

d. Skills

Table 14. Descriptive Data Skills Daima Hotel Padang

\begin{tabular}{|c|c|c|c|}
\hline Category & Score Range & Frequency & $\%$ \\
\hline Very Good & $\geq 7.9$ & 15 & 30.61 \\
\hline Good & $6.6-<7.9$ & 16 & 32.65 \\
\hline Enough & $5.3-<6,6$ & 10 & 20,40 \\
\hline Poor & $4-<5,3$ & 8 & 16,32 \\
\hline Very bad & $<4$ & 0 & 0 \\
\hline \multicolumn{2}{|c|}{ Total } & 49 & 100 \\
\hline
\end{tabular}


The descriptive data table explains that: $30.61 \%$ very good category, $32.65 \%$ good, 20 , $40 \%$ is sufficient, and $16.32 \%$ is bad. So, it was concluded that skills Daima Hotel Padang employees rated good.

e. Instruction Capability

Table 15. Descriptive Capability Data of Instruction Daima Hotel Padang Capability

\begin{tabular}{|c|c|c|c|}
\hline Category & Range Score & Frequency & $\%$ \\
\hline Very Good & $\geq 7.9$ & 22 & 44.89 \\
\hline Good & $6.6-<7.9$ & 20 & 40.81 \\
\hline Enough & $5,3-<6,6$ & 3 & 6,12 \\
\hline Poor & $4-<5,3$ & 4 & 8,16 \\
\hline Very Bad & $<4$ & 0 & 0 \\
\hline \multicolumn{2}{|c|}{ Total } & 49 & 100 \\
\hline
\end{tabular}

The descriptive data table explains that: $44.89 \%$ very good category, $40.81 \%$ good, $6.12 \%$ fair, and $8.16 \%$ bad. So, it is concluded that the capture power of the instructions Daima Hotel Padang employees is considered very good.

f. Initiative

Table 16. Descriptive Data of Daima Hotel Padang Initiative

\begin{tabular}{|c|c|c|c|}
\hline Category & Score Range & Frequency & $\%$ \\
\hline Very Good & $\geq 7.9$ & 23 & 46.93 \\
\hline Good & $6.6-<7.9$ & 16 & 32.65 \\
\hline Enough & $5.3-<6.6$ & 2 & 4,08 \\
\hline Poor & $4-<5,3$ & 8 & 16.32 \\
\hline Very Bad & $<4$ & 0 & 0 \\
\hline \multicolumn{2}{|c|}{ Total } & 49 & 100 \\
\hline
\end{tabular}

The descriptive data table explains that: $46.93 \%$ is a very good category, $32.65 \%$ good, $4.08 \%$ sufficient, and $16,32 \%$ bad. So, it was concluded that the initiative Daima Hotel Padang employees are considered very good.

\section{Analysis Requirements Test}

Based on the analysis requirements test, it can be concluded that the three variables are normally distributed, then the data is homogeneous and there is a linear relationship. 


\section{Hypothesis Testing}

Obtained Regression coefficient reward 0.318 and significant $0.00<0.05$ means that reward has a significant effect on performance. Then punishment 0.519 , the significance is $0.00<0.05$, it means that punishment has an influence on performance. Obtained $\mathrm{F}$ count 11.797 the significance of $0.000<0.05$ means that reward and punishment simultaneously affect the performance of employees at Daima Hotel Padang. Then the contribution of the effect of reward and punishment on performance is $39.9 \%$ and $60.1 \%$ is influenced by other factors.

\section{Discussion}

a. Reward

Reward enough classified category with the percentage $79.59 \%$. Furthermore, the results of the data description per indicator can be grouped as follows: 1) salary and bonus, categorized as adequate, percentage $32.65 \%, 2$ ) welfare, categorized as sufficient, percentage $46.93 \%, 3)$ career development, categorized as good, percentage 48, 97\%, 4) psychological and social rewards, categorized as sufficient, the percentage is $42.85 \%$. The effect of reward can be categorized as sufficient, the hotel should review the reward that has been set on the employees of Daima Hotel Padang.

b. Punishment

Punishment is in the bad category with the percentage of $44.89 \%$. Furthermore, the results of the data description per indicator can be grouped as follows: 1) light punishment, categorized as bad, the percentage of $42.85 \%, 2$ ) moderate punishment, categorized as bad, the percentage of $51.02 \%, 3$ ) severe punishment, categorized as sufficient, percentage $55,10 \%$. The effect of punishment can be categorized as bad, the hotel should emphasize more punishment so that employees are more disciplined towards the regulations that have been set at Daima Hotel Padang.

c. Employee Performance Employee

performance is in the good category with a percentage of $85.71 \%$. Furthermore, the results of the data description per indicator can be grouped as follows: 1) knowledge of work, categorized as good, percentage $32.65 \%, 2$ ) quality of work, categorized as very good, percentage $53.06 \%, 3$ ) quantity of work, categorized as very good, percentage $40.81 \%, 4$ ) skills, categorized as good, percentage $32.65 \%, 5$ ) comprehension of instructions, categorized very good, percentage $44.89 \%$, 6) initiative, categorized as very good, percentage $46.93 \%$. Based on the description above, it can be classified as good employee performance, Daima Hotel Padang employees should be able to maintain or improve their performance because good performance can achieve company goals.

d. The Effect of Reward and Punishment on Employee Performance

Contribution of effect reward with a coefficient value of 0.318 , the significance is 0.00 $<0.05$, so that the reward has an influence on employee performance. Then punishment is obtained with a coefficient value of 0.519 with a significant $0.00<0.05$, then punishment has an effect on performance. While the decision making uses the F test with an F value of 11.797 with a significant value of $0.000<0.05$, which means reward and punishment that simultaneously have a significant effect on the employee performance of Daima Hotel Padang. Furthermore, the regression coefficient value is 46.022 , which means that each increase of 1 
independent variable unit can increase 46.022 units of the dependent variable. Increased reward and punishment will have an impact on improving the performance of Daima Hotel Padang employees.

\section{Conclusion}

a. Overall, the rewards at Daima Hotel Padang show a moderate category with a percentage of $79.59 \%$. Meanwhile, based on 4 indicators, there is 1 good category indicator, namely career development indicator and 3 sufficient category indicators, namely salary and bonus, welfare and social psychological rewards.

b. Overall, the punishment at Daima Hotel Padang shows a bad category with a percentage of $44.89 \%$. Meanwhile, based on 3 indicators, there is 1 sufficient category indicator, namely severe punishment and 2 bad category indicators, namely light punishment and moderate punishment.

c. Employee performance at Daima Hotel Padang as a whole is good with a percentage of $85.71 \%$. Then based on the 6 indicators there are 3 good category indicators, namely knowledge of work, skills and initiative and 3 indicators of very good categories, namely quality of work, quantity of work and capturing power of instructions.

d. Based on this research, the results of the effect of reward and punishment on employee performance is $39.9 \%$ and $60.1 \%$ are influenced by other factors. Thus, the hypothesis of this study isHa welcome and $\mathrm{HO}$ rejected.

\section{References}

[1] Arikunto. 2010. Research Procedure A Practice Approach. Jakarta: Rineka Cipta.

[2] Mangkunegara. 2015. Human Resource Management. Bandung: Youth Rosdakarya.

[3] PPRI No.65.2001. "Hotel"

[4] http://www.hukumonline.com/pusatdata/downloadfile/it4e15698cdb79f/parent/lt4e1564addd384

[5] Law No.10.2009. "Tourism" http://jdih.kemenpar.go.id/dokumen/file-pdf/4636 1364-UUTentangKepwisataannet.Pdf.pdf

[6] Wibowo. 2016. Performance Management. Jakarta: PT RajaGrafindo Persada.

[7] Widyaningsih. 2017. "The Effect of Rewards and Punishment on Employee Performance of PT. Kereta Api Indonesia (KAI) Persero DAOP V Purwokerto Kutoarjo Station ". Journal of the Faculty of Economics, Muhammadiyah University of Purworejo. 